\title{
Building a Wall Around Tudor England: Coastal Forts and Fantasies of Border Control in Friar Bacon and Friar Bungay
}

\begin{abstract}
This article examines the border wall and the image of fortress England in Robert Greene's Friar Bacon and Friar Bungay and early 1590s nationalist discourse. While Greene recognizes the need for an international outlook in geopolitics, Bacon's wall speaks to contemporary interest in coastal fortifications and brass ordnance in the wake of the Spanish Armada. Greene lampoons the wall as magical thinking, but the play clings to metaphorical walls as more cost-effective symbols of national security and autonomy. The play's awkward combination of pan-European sentiment and strident nationalism offers a prophetic commentary on post-Brexit Britain.
\end{abstract}

In a 2019 dystopian novel by John Lancaster, a perplexed recruit finds himself patrolling a colossal border wall encircling all of Britain. Despite the novel's unmistakably topical intent, the conceit of a walled-off Britain is not without precedent in English literature. In the late Elizabethan comedy The Honourable History of Friar Bacon and Friar Bungay, a medieval magician dreams of engirdling the shores of England with a defensive wall of brass. Since the English and Welsh coastline extends for 5,881 miles $(8,982 \mathrm{~km})$, this brazen wall would be an engineering feat that would make Hadrian's Wall — a mere eighty-four miles - look like a catwalk, and would in fact have rivalled the Great Wall of China in scale. As a structure of such size and expensive material was well beyond the Tudor state's technological and fiscal means, Friar Bacon must resort to the supernatural to construct it. In the end, to Bacon's chagrin, his much-vaunted wall never materializes, and the playwright Robert Greene seems to parody the jingoistic fantasy as magical thinking or politically misguided braggadocio (as the recurrent pun on brazen subliminally hints). The proposed wall in Friar Bacon nevertheless invites close scrutiny because in several respects Greene's comedy echoes the patriotic and religious propaganda hailing England as an 'elect nation'

Todd Andrew Borlik (T.Borlik@hud.ac.uk) is a senior lecturer in the department of English, linguistics, and history at the University of Huddersfield. 
in the wake of the Spanish Armada's retreat. In our current political climate, re-examining the rhetoric of wall-building in Tudor England in ideological discourses of national insularity is almost irresistible. Rather than inspect the wall from our own present moment, however, this article approaches it from a more historicist bent. Specifically, it takes the measure of Bacon's brass wall by reading it alongside the campaigns to build and refortify a network of artillery castles along England's coastline, and to equip the English navy with brass (now called bronze) cannonry - campaigns in which leading patrons of the acting companies that performed this play were involved. In Greene's comedy, the magus's plan to erect an actual material wall fails spectacularly, but this failure does not diminish its potency as an emblem of English nationalism, as the final scene of Friar Bacon reimagines the wall as a tree-like Tudor rose bestowing a figurative protection over England's borders.

\section{Foundations for the Wall}

As brass has long been synonymous with durability, the presence of brazen defences in ancient texts should come as no surprise. In Homer's Odyssey, for instance, brass walls encircle the island of the wind god Aelous. The Roman poet Horace speaks of Troy as protected by murus aeneus, or brazen walls. ${ }^{1}$ Brass gates and walls also appear in the Hebrew bible, and these passages, as we shall see, had a profound influence on English Protestants following Henry VIII's split from the Roman Catholic Church. In the early modern era poets, playwrights, and religious writers invoke brass fortifications with increasing frequency. Lisa Hopkins records several allusions to brass towers in plays such as The Spanish Tragedy, Wily Beguiled, and The Love-Sick King, and notes that the structure functioned in the early modern imagination as a 'byword for invincibility' at a time of growing nationalist fervour. ${ }^{2}$ The reference in The Spanish Tragedy is particularly noteworthy, as Thomas Kyd's tragedy is contemporaneous with both Greene's comedy and the Armada scare, when national defence was in the forefront of public consciousness. As the following pages elaborate, brass walls were encrusted with classical, religious, and militaristic connotations when Greene made them a major plot point in Friar Bacon.

Whoever first conceived of girdling England in brass is not entirely clear; nor do we know for certain where Greene encountered the scheme, if indeed he did not invent it. Greene's comedy is partially based upon legends of a historical monk, Roger Bacon, who lived in Oxford in the thirteenth century. Although Bacon might be dubbed a techno-futurist, and a letter attributed to him speaks 
of marvels like submarines and flying machines, the only evidence to support the claim that he ever proposed a national wall comes from a conspicuously fictionalized romance published centuries after his death. ${ }^{3}$ In The Famous Historie of Fryer Bacon, the eponymous scholar explicitly conceives of the wall as a bulwark against the threat of invasion:

Fryer Bacon, reading one day of the many conquests of England, bethought himself how he might keep it from the like conquests, and so make himself famous hereafter to all posterities. This (after great study) hee found could be no way so well done as one: which was to make a head of Brass; and if he could make the head to speak (and hear it when it speaks) then might hee be able to wall England about with Brass. ${ }^{4}$

While the earliest extant version of The Famous Historie dates from 1627, literary historians presume that Greene knew an Elizabethan version of it that has not survived. 5 Curiously, however, a similar fantasy occurs in Doctor Faustus, when Marlowe's conjuror speaks of commanding his spirits to 'wall all Germany with brass' (1.1.190). 6 Since Friar Bacon and Friar Bungay is likely a Faustus knock-off (both plays date from ca 1588-90), Greene feasibly could have lifted the idea from Marlowe. ${ }^{7}$ This possibility would invite the inference that either Marlowe first proposed the wall or was acquainted with Greene's lost source-text. That someone instead could have interpolated the brass wall reference in Faustus at a later date when Marlowe's play was revived in repertory with Friar Bacon seems unlikely but we cannot completely discount this hypothesis given Faustus's messy textual history. Another possible scenario is that Greene, Marlowe, or the unknown author of The Famous Historie based the wall on an episode in book 3 of Spenser's Faerie Queene (1590). When Britomart approaches Merlin's cave, Spenser explains why it echoes with the 'rombling' sound of 'brasen Caudrons':

The cause some say is this: A litle whyle

Before that Merlin dyde he did intend,

A brasen wall in compass to compile

About Cairmardin, and did it commend

Vnto these Sprights, to bring to perfect end.

(III.iii.10) $)^{8}$

Michael Drayton repeats this legend in Poly-Olbion, claiming that Arthur's wizard not only transported Stonehenge from Ireland in a single night but also planned to environ Carmarthen in a brass wall: 'And for Carmardens sake, would have fain have brought to pass / About it to have built a wall of solid Brasse' (4.331-2). ${ }^{9}$ John Henry Jones speculates the brass wall 'was not part of the traditional myth 
of Bacon, but injected from Spenser'. ${ }^{10}$ Spenser's prefacing of the tale with 'some say', however, suggests, if taken literally, that he may have drawn on a pre-existing literary or oral tradition, and Greene or the author of The Famous Historie would still deserve credit for expanding the wall from the borders of one Welsh county to the entire English and Welsh coast.

What emerges from this muddle is that the dream of a walled-off England is not so much a medieval invention but one that truly begins to grip the English imagination in the late sixteenth century during the panic triggered by the Spanish Armada. Spenser's attributing a defensive wall to Merlin is particularly apt as it befits The Faerie Queene's strident nationalism. Uncoincidentally, Merlin is a figurehead for Britishness, and prophesies of the coming of Arthegall, 'Strongly to ayde his country to withstand / The powre of forreiene Paynims, which invade thy land' (III.iii.27). Significantly, however, Merlin's wall proves to be a monumental failure. In both Spenser and Drayton, he is imprisoned in a cave by Nimue, the Lady of the Lake, and never completes it. A similar storyline unfolds in Friar Bacon and Friar Bungay, as the conjuror falls asleep at the critical moment his oracular brass head utters its secrets that would have enabled Bacon to raise the walls. Nevertheless, abandoning the plan of a physical wall does not diminish the ideological potency of what the wall represents; it still functions as a rhetorical tool for imagining a unified and impenetrable England without laying a single brick or forging a single brass sheet of it.

\section{Bacon's Wall and Anglo-European Diplomacy}

The subject of English identity and the early modern construction of English nationhood has received a great deal of attention from a number of formidable scholars, such as Richard Helgerson, Jeffrey Knapp, Andrew Hadfield, Claire McEachern, Andrew Escobedo, and Philip Schwyzer. ${ }^{11}$ Somewhat surprisingly, however, none of these studies examines Friar Bacon and Friar Bungay or the topic of a nation-engirdling wall. In a recent monograph, Adam McKeown demonstrates that the militarized city functions as 'an ideal not only of design but also of social and political organization, which was developed extensively but also critiqued in utopian literature of the period'. ${ }^{12}$ A similar argument can be made about the fortified nation, which was not simply a fantastical castle-in-the-sky but a military strategy and figurative trope with real purchase in late Tudor England, and Greene's comedy shares much of the ambivalence of the utopian texts vetted by McKeown. ${ }^{13}$ While Barbara Traister, Deanne Williams, and Brian Walsh have incisively analyzed the nationalistic overtones of Friar Bacon and Friar Bungay, 
Greene's play demands reassessment as the most significant commentary on a national wall-building project in early modern English literature. ${ }^{14}$

But is it in fact a nationwide wall? When Bacon unveils his plans for the wall in the second scene of the play, the first in which he appears, the text is somewhat ambiguous on this point. With the aid of a talking brazen head (a magical device with a long pedigree in medieval romance), Bacon professes he will devote his esoteric knowledge to the cause of national defence:

And I will strengthen England by my skill,

That if ten Caesars lived and reigned in Rome,

With all the legions Europe doth contain,

They should not touch a grass of English ground.

The work that Ninus reared at Babylon,

The brazen walls framed by Semiramis,

Carved out like to the portal of the sun,

Shall not be such as rings the English strand,

From Dover to the marketplace of Rye.

$(232-40)^{15}$

This passage supplies both a motive and a classical exemplum for the enterprise. The allusion to Caesar recalls the Roman invasions of Britannia, both the aborted campaigns ordered by Julius Caesar in 55 and $54 \mathrm{BCE}$ as well as the successful conquest during the reign of Emperor Claudius in $43 \mathrm{CE}$. In this detail, Greene presumably was following his source, The Famous Historie, in which Bacon conceives of the wall after reading in ancient chronicles of the four invasions of Britain. When we juxtapose The Famous Historie and Greene's Honorable Historie, however, some notable differences emerge. In the former, Bacon intends to wall the entire nation. The play maintains this view when the Oxford don Burden reports a rumour that Bacon intends 'to compass England with a wall of brass' (204), and Bacon later confirms that he plans to 'girt fair England with a wall of brass' (1583). Crucially, however, in the passage cited above Bacon speaks of the wall stretching only from Dover in Kent to Rye in East Sussex - a relatively modest distance of around twenty-eight miles (forty-five $\mathrm{km}$ ) in comparison to the whopping figure of 5,881. One might argue that Bacon possibly means the wall to wrap counterclockwise from Dover all the way around to Rye, but this model would leave a gap in the place most vulnerable to invasion directly across the Channel from Calais. Since Bacon, in the same scene, asserts he will 'circle England round with brass' (351), the play depicts the friar himself as somewhat uncertain about the scale of the project. The inconsistency is revealing; the exact dimensions and location of 
the wall are, in other words, not as important as the idea of it as a metaphor to conjure with, as it were, in the discourse of nationhood.

Bacon's allusion to Semiramis is not found in The Famous Historie and thus also appears to be Greene's own addition. The reference is noteworthy in that the late Tudor era witnessed the rehabilitation of Semiramis by Protestant defenders of Elizabeth, who saw the Babylonian queen, despite her reputation as a sybarite, as a precedent for strong female rulers. While acknowledging that she did eventually 'degenerate into great vices', John Bridges asserts, 'yet for a greate while, both in the noneage of her sonne, and afterwarde also in respect of worldly pollicie, power, and magnificence, shee wonderfullie gouerned about fortie yeeres, that mightie, golden, and first monarchie of the Assyrians and Chaldeans, and the most Hystoriographers that write of her life, haue her actes in admiration'. ${ }^{16}$ Chief among Semiramis's admirable acts was the construction of an enormous wall around her capital. Herodotus (whose landmark history had been translated in 1584) reports that the walls of Babylon were a staggering fifty-six miles long, eighty feet thick, and 320 feet tall. An Elizabethan history lists similarly impressive dimensions: 'Her walles wer of an incredible magnitude and strength, being fifty cubites in breadth, and 300 cubites in higth. The circute and compasse of it is sayd to be 480 furlonges ... The walles were made of bricke, compacted together wt lime $\&$ pitch ... [and] beutified wt an hundred gates of bras. ${ }^{17}$ Although only its gates were brass, Babylon provides an important historical model for Bacon's wall-building. Like the suggestion that the wall might only extend from Dover to Rye, the success of Semiramis makes Bacon's wall sound less far-fetched, offering a reminder that a civilization might erect such monumental structures, and with a female ruler on the throne. ${ }^{18}$

Greene's depiction of the wall, however, is far from straightforward. Despite the evident appeal of a border wall in an era rife with fears of foreign invasion, the comedy also represents it as a hubristic and perhaps even demonic enterprise. Burden accuses Bacon of enlisting a construction crew of 'devils and ghastly fiends' (202), and the friar confirms that he will employ 'Nigromancy' (228) that is, invoke black spirits - to build it. Such passages code the wall as a diabolical undertaking. More pointedly, Bacon never even begins the wall, much less completes it, since his feckless assistant fails to wake him at the critical juncture when the brazen head speaks. In hindsight, Bacon confesses that the wall was an arrogant scheme (as the pun on 'brazen' implies), beyond the scope of what is permitted to mortals, and accepts the judgment of the divine power that smashed his oracular head (and hence his hopes for the wall) when he smashes his own enchanted glass. 
In lieu of the wall, the comedy substitutes the far more practical strategy for securing England's peace through marriage alliances with the royal households of Europe. Just as Bacon abandons his dream of the wall, Prince Edward must relinquish Margaret, the 'fair maid of Fressingfield', to his friend Lacy and instead marry Eleanor of Castile to promote peace with this Spanish kingdom. To be sure, national bragging rights are at stake in the wizards' duel between Bungay and the German conjuror Vandermast; however, the magic they wield is neither English nor German, but derived from occult texts originating in Egypt and ancient Greece and recovered by Italian humanists. When Bacon prevails, King Henry declares he has 'honoured England' (1284), yet the king's willingness to cooperate and forge alliances with European powers tempers his patriotic pride in the beauty of the English landscape, and in the elegant architecture and intellectual prowess of Oxford. ${ }^{19}$ The alliance is cemented in the conviviality of the marriage feast, featuring a cornucopia of exotic delicacies imported from around the world: Egypt, Persia, North Africa, Candy (Sri Lanka), Spain, Judea, and Rome. The menu for the feast that concludes the play celebrates England's participation in pan-European, even global commerce. Greene himself apparently had a fatal love of imported Rhenish wine, and had in fact travelled widely on the continent - visiting Italy, Spain, France, Germany, and Poland. The author of Friar Bacon and Friar Bungay does not seem to be, in other words, what we in modern parlance would call a 'Little Englander'.

Critical opinion for the most part supports the view that Greene's comedy looks askance at the nationalist rhetoric that undergirds the wall. Although she is more interested in how the play deconstructs the historical boundaries between the medieval and early modern rather than national boundaries, Williams has remarked that the smashing of Bacon's plans for the wall 'undoes the dream of national insularity'. ${ }^{20}$ Seizing on Bacon's allusion to Brutus (Aeneas's descendent who settled Britain) during the wedding feast, Williams argues that Greene, while aware of the inevitable demise of empires, rejects the wall by appealing to a shared European history and culture that unifies England and the continent. Traister similarly deciphers the moral of the play as a warning against isolationism: 'England's glory can best be served not by shutting her off from the rest of the world with Bacon's wall but allowing her communication and interchange with other countries ... There is no need for, but rather danger in, England's withdrawal behind brass walls. ${ }^{21}$ While I applaud the sentiments behind these interpretations, my reading of Friar Bacon and Friar Bungay sees Greene as somewhat more conflicted or uncertain. Throughout his brief writing career, Greene vacillated between a sense of himself as a cosmopolitan intellectual and a desire 
to be a popular and profitable author among more fervent Protestant readers and audiences in London at a time when patriotic sentiment ran high and anxieties of a second Armada invasion still simmered. Both these authorial personas (homo academicus and poeta publicus, in Bryan Reynold's and Henry Turner's formulation) are present in much of his work, and the attempt to reconcile them in Friar Bacon and Friar Bungay is in large measure what gives the play its complexity. ${ }^{22}$ Ultimately, however, the two may not be reconciled so much as held in an uneasy suspension. By the same token, nationalism and multilateralism need not be mutually exclusive, and Greene may not soundly reject the former in favour of the latter but simultaneously pursue both with an ambivalence that continues to vex Anglo-European politics to this day.

In his History of Henry VII, Francis Bacon recounts that the king brokered marriages between his daughters and the rulers of Scotland and France, and that these alliances were as pleasing to him 'as if hee thought hee had built a Wall of Brasse about his Kingdome. ${ }^{23}$ While this simile appears to be Francis Bacon's rather than Henry's, it does suggest that marriage alliances can promote international harmony and national insularity at the same time. Greene arguably portrays Edward's marriage to Eleanor of Castile as an aggrandizement of England rather than an absorption of it into a pan-European partnership. Tellingly, the wedding scene and play conclude with Bacon's vision of other European nations bowing before Queen Elizabeth, and the play's final line is unabashed jingoism: 'Thus triumphs England over all the west' (2155). Edward I, moreover, was hardly a model of amicable international diplomacy, but would go on to subjugate Scotland and Wales, constructing a ring of castles at strategic points around the Welsh coast. Greene's prince was, in other words, the chief architect behind the colonizing scheme to make England congruent with the island of Britain, reinforcing insularity as a keystone of English identity. Greene's audiences, furthermore, would have known that these marriage alliances with France and Spain were by no means a safeguard of European peace. Having conducted a successful invasion of Britain himself, Henry VII was acutely aware of its vulnerability, and he continued to invest in national defence while negotiating European alliances. After his divorce from a Spanish princess, Henry VIII spent lavish sums on constructing artillery fortifications along the English coast, and his daughter Elizabeth continued these building projects at times of heightened threat, such as the Armada scare of the late 1580s. Situating Bacon's brass wall within the history of Tudor military engineering projects sketches a more nuanced picture of the play's politics, and of the image of fortress England in discourses of English nationhood. 


\section{Bacon's Wall and The Practise of Fortification}

In a work debunking musty fables, Thomas Browne proposes that Bacon's brazen head was an alchemical experiment to transmute lead into gold, and the brass wall a cryptic allusion to the 'most powerful defence, and strongest fortification which gold could have effected'. ${ }^{24}$ Browne's opinion is often cited in the scholarship on Friar Bacon, but his line of reasoning has not been pursued with the diligence it merits. While it would be reductive to push an allegorical reading of Greene's comedy, there are some striking parallels in the rhetoric that buttresses both Bacon's brass wall and the Tudor state's spree of fortress building. After the suppression of the northern Catholic uprising known as the Pilgrimage of Grace, Henry VIII turned his attention to the threat of foreign invasion in the south. $\mathrm{He}$ developed an ambitious defence strategy known as the 'King's Device' to ring the English coast with artillery forts, based on the latest in Italian and German engineering. Between 1539 and 1547, the English government erected twenty-two of these so-called 'Device Forts', from Dale in Pembrokeshire to Harwich in Essex. The direction of this treasury-draining project was put into the capable hands of Thomas Cromwell, who funded the construction with the wealth confiscated from the monasteries. In the 1540s, England's abbeys were not only dismantled but effectively transformed into artillery forts. The twenty-two that Henry managed to construct represent only a small proportion of what he envisaged: 'the Henrician castles that exist today along the south coast of England are the surviving vestiges of a much broader scheme ... to protect the coastline of Britain from Berwick on the Anglo-Scottish border down to Kent, along the south coast, and up to South Wales. ${ }^{25}$ In other words, Henry VIII dreamed of encompassing England in a ring of coastal fortresses that would have been tantamount to walling the nation in brass.

Even with the tremendous capital siphoned from the Church, however, Henry could not fund all the castles he wished, and chose to focus on Dover and the vulnerable Cinque Ports of the south coast across the Channel from France. By the late sixteenth century, the Cinque Ports had come to include Rye, which then featured a decaying tower (Ypres Tower) constructed by Henry III, the very king who appears in Greene's comedy. In 1539, Henry VIII ordered the construction of a massive artillery fort at Camber right beside Rye and equipped it with twentyeight brass and iron cannons. In a curious coincidence, the advent of gunpowder, a substance the Chinese invented but that none other than Roger Bacon first described in the west, necessitated this extensive refurbishment and expansion of England's coastal defences. ${ }^{26}$ Gunpowder and improvements in naval artillery 
made Tudor England, especially after the split with Rome, feel more vulnerable to invasion. While only a small percentage of Greene's audience may have known of Friar Bacon's role in bringing gunpowder to the attention of Europe, Bacon's plan to build a wall 'from Dover to the marketplace at Rye' would strike a chord with Tudor playgoers, as these harbours remained cornerstones of England's national defence in the late Elizabethan period. In fact, the appearance of Greene's play on the London stage by the Queen's Men and Admiral's Men coincides with an upsurge of interest in military fortifications, and prominent figures connected to these two acting companies were at the forefront of it.

In 1589, either shortly before or after the premiere of Friar Bacon, Paul Ive published The Practise of Fortification, a landmark treatise on military engineering in the post-gunpowder age. As a blacksmith's son turned soldier and spy, Ive (or Ivy) could boast of a knowledge that was not purely theoretical: he had infiltrated and studied some of the new citadels built by the Spanish in the Low Countries, and has been dubbed the 'leading English consultant on fortifications' in Elizabeth's reign. ${ }^{27}$ The Tudor state employed him in engineering projects at Dover Harbour in the late 1580s, and again at the Chanel Islands in 1593. Three years later, Ive was appointed to survey the Cinque Ports (including Rye) to estimate the expenses for improving the southern coastal forts, recommending major upgrades to Dover Castle. ${ }^{28}$ In other words, Ive was the brains behind the push to refortify the nation's border defences at the very two harbours Friar Bacon mentions as possible endpoints for his brass wall.

Could Robert Greene have known of Ive's Practise of Fortification? The playwright Christopher Marlowe certainly did, as evident from this passage in Tamburlaine the Great, Part II:

The ditches must be deep,

... The walls made high and broad,

The bulwarks and the rampiers large and strong

With cavalieros and thick counterforts,

And room within to lodge six thousand men.

It must have privy ditches, countermines,

And secret issuings to defend the ditch.

It must have high argines and covered ways

To keep the bulwark fronts from battery.

As Marlowe scholars have noted, this speech is copied almost verbatim from Ive's treatise: 
[A fort needs] deep ditches, high walls, great bulwarks, large ramparts and cavalieros. Besides, it must be large to lodge fiue or six thousand men ... It must also have countermines, priuie ditches, secret issuings out to defend the ditch, casmats in the ditch, couered wayes round about it, and an argine or banke ... and other things necessarie for the keeping of it. ${ }^{30}$

Since the Tamburlaine sequel probably dates from 1588, Marlowe must have seen Ive's work in manuscript, most likely, as Charles Nicholl has speculated, through their mutual contacts in the intelligence network of Sir Francis Walsingham. ${ }^{31}$ Ive, like Marlowe, worked as an agent for Walsingham. In fact, Ive dedicated The Practise of Fortification to Walsingham and William Brooke, the lord warden of the Cinque Ports, acknowledging the 'manifold benefits' he had received from them over the years. ${ }^{32}$ The dedication to Walsingham should catch the eye of theatre historians as the queen's secretary and spymaster also helped establish the Queen's Men, the very playing company that first performed Friar Bacon and Friar Bungay sometime around 1589.33 Bacon's dream of a nation-encircling brass wall would certainly have piqued the interest of a militant Protestant like Walsingham with a documented interest in artillery fortifications. Cutting-edge fortification technology was an even more topical subject in 1589 than the scholarship on Friar Bacon has appreciated. As Greene and Marlowe moved in similar circles, the distinct possibility that Greene, too, knew of Ive's border defences further increases the likelihood that Bacon's brass wall, despite its supposedly medieval and magical origins, embodies the contemporary obsession with military engineering technology during the Armada scare. ${ }^{34}$

I have said little up to this point about the fact that Bacon intends to forge his wall of brass. For the sake of clarity, I should note that in early modern usage the word 'brass' encompassed what we now call bronze, and the two were only differentiated in the mid-eighteenth century. ${ }^{35}$ Both are copper alloys, and brass simply includes zinc whereas bronze is mingled with tin. In the sixteenth century, Henry VIII, Queen Elizabeth, and the Lord Admiral Howard invested heavily in cannons made of both iron and bronze (then called brass), and the latter was increasingly preferred due, in part, to the havoc the iron industry wrought on England's woodlands. In a speech delivered before Parliament in 1593, John Fortescue praised the queen for outfitting the navy with brazen ordnance: 'She did find in her navy all iron pieces, but she hath furnished it with artillery of brass. $^{36}$ The extensive renovations to the castle at Berwick-upon-Tweed in the Elizabethan period included the creation of a 'brass bastion', so-called because it housed brass (bronze) cannons. Bacon's scheme of a brass or brazen wall resonates 
with England's acquisition of brass artillery that was vital to the nation's defence strategy in the Tudor period, and especially around the time of the Armada.

Whether Greene composed the play before or after 1588, fears of a Spanish invasion still lingered when the play was likely revived in 1590s. Henslowe's so-called diary records that 'fryer bacone' was performed at the Rose at least nine times between 1592-93. ${ }^{37}$ Although scholars have suggested that some of these productions by Lord Strange's Men might actually have been a spin-off now known as John of Bordeaux, memories of Bacon and his wall clearly did not fade. ${ }^{38}$ Greene's play was printed in 1594 , and when a group of the Queen's Men reformed as the Lord Admiral's company later that year, they took Friar Bacon with them. Their new patron, Charles Howard, was, like Walsingham, a vocal supporter of naval defence, tasked with refortifying the castles along the sea-coast. He, too, apparently knew of Paul Ive. In 1595, Howard recommended Ive to oversee the improvements to the harbour defences at Portsmouth. ${ }^{39}$ Howard's company, the Admiral's Men, was still staging Friar Bacon in December 1602, when Henslowe paid Thomas Middleton five shillings to compose a new prologue and epilogue for a court performance. ${ }^{40}$ Although Middleton's additions have not survived, we can reasonably bet that his epilogue echoed Bacon's original prophecy in paying fulsome tribute to the queen, further confirming that her reign would be remembered as a time of peace and national pride. In his reading of Bacon's prophecy, however, Brian Walsh calls it a 'backhanded compliment', and observes that its ode to the Pax Elizabetha may have stirred anxieties that England will not be able to sustain the peace after her reign. ${ }^{41}$ Audiences may have felt such concerns even more acutely during the play's 1602 revival. Bacon's mystical vision is not one of perpetual concord but only a temporary respite, and Walsh goes on to say that the defeat of the Armada did not allay fears of a future invasion or 'foreclose the possibility of future Spanish or indeed Catholic threats. ${ }^{42}$ Given the provenance of Friar Bacon with the Queen's Men, and the company's links through Walsingham to military engineers (as documented in Marlowe), Greene's comedy could be taken as an endorsement, albeit an ambiguous one, of increased spending on coastal defences by vehemently Protestant factions at court.

Allusions to Bacon's wall continue to crop up well into the Jacobean period, when the nationalist fervour cooled, and the king was pursuing alliances with Europe. Wall-building features in an anonymous 1606 play, in which a character dreams of erecting a wall around London: ' $\mathrm{O}$ this Citty ... be it spoken in secret, Ile haue fenst about with a wall of brasse'. ${ }^{43}$ Another 1606 play, John Marston's The Fawn, recalls Bacon's attempt: 'They say in England that a farre-fam'd Frier 
had guirt the Island round with a brasse wall, if that they could haue catched, Time is, but Time is past, left it hill clipt with aged Neptunes arme.' ${ }^{44}$ As this passage from Marston suggests, abandoning the wall does not mean abandoning the idea of a fortified and isolationist England. In the final section of this article, I turn from literal walls to metaphorical walls to proffer a more nuanced assessment of the nationalism of Friar Bacon and the late Elizabethan era.

\section{Fortress England and Metaphorical Walls}

The passage from Marston cited above raises the prospect that some of Greene's contemporaries might have considered walling a 'hill clipt' island an exercise in lily-gilding. After all, early modern English literature resounds with tributes to the geographical blessings that make the nation a natural fortress. The locus classicus for this sentiment is of course John of Gaunt's oration in Shakespeare's Richard II, in which the sea performs 'the office of a wall' (2.1.47). ${ }^{45}$ Through the still-common 'topographical slippage' between England and Britain, the speech presents insularity as the 'defining feature' of English identity. ${ }^{46}$ Shakespeare recycles the jingoistic metaphor in Cymbeline, but places it in the mouth of the sinister queen, who urges Cymbeline to defy the Romans while reminding him of

the natural bravery of your isle, which stands

As Neptune's park, ribbed and paled in

With oaks unscalable and roaring waters,

With sands that will not bear your enemies' boats,

But suck them up to th'topmast.

A deer park surrounded with a wooden pale seems far less daunting than Gaunt's wall or moat, much less Bacon's brass wall. While oaks might signify wooden war ships, recalling the English navy's victory over the Spanish fleet, the queen's villainous behaviour undercuts her isolationist policy. In the tonal differences between the speeches in Richard II and Cymbeline, Shakespeare registers the change from the zealous patriotism of the Armada years under Elizabeth to the more Euro-friendly outlook of the pacifist King James. ${ }^{47}$

While these excerpts from Richard II and Cymbeline are well known, critics sometimes forget that Robert Greene peddled the vision of fortress England long before Shakespeare, that 'upstart crow, beautified with our feathers' as Greene notoriously smeared him. Indeed, Richard II dates from ca 1594-96, right around the time that Friar Bacon and Friar Bungay was first printed, and Shakespeare's image of a 'sea-walled' England and Richard's contrast between human flesh and 
a wall of 'brass impregnable' $(3.4 .44,3.2 .164)$ may owe something to Greene's comedy. In scene 4 of Friar Bacon and Friar Bungay, King Henry III greets the German emperor and the king of Castile with a geography lesson:

Great men of Europe, monarchs of the west,

Ringed with the walls of old Oceanus,

Whose lofty surge is like the battlements

That compassed high-built Babel in with towers,

Welcome, my lords, welcome, brave western kings,

To England's shores, whose promontory cleeves

Shows Albion is another little world.

This curious speech neatly encapsulates the ambiguities that dog the play. King Henry appears to be boasting of his realm's invulnerability and exceptionalism, but also reveals that the fortress England metaphor slices both ways. While the drift of the speech seems to be that the 'walls of old Oceanus' protect England from Europe, the syntax hints that these same watery walls fortify Europe against invasion by England. Henry's invocation of Albion's white 'cleeves' or cliffs on the southern coast depicts them as another geographical bulwark. Picking up on Henry's bluster, however, the king of Castile retorts in kind by explicitly likening his country's topography to natural fortifications when he hails the 'Pyren mounts swelling above the clouds, / That ward the wealthy Castile in with walls' (460-1). Clearly, England is not unique in possessing boundaries aligned with topographical features that aid in national defence.

The wall motif recurs a few lines later in the same scene when Castile's daughter Eleanor admires the English prince for his feats 'done at the holy land fore Damas walls' (472). This line intimates that a common Christian faith greater than any narrow tribal allegiances unifies the European powers, and again the wall acts as both a literal and symbolic border for defining community. Although Greene speaks of Damas or Damascus, Edward actually fought to defend the besieged crusader stronghold of Acre, which ultimately fell in 1291. In other words, Edward's feats in the Ninth Crusade turned out to be futile, and the city's heavily fortified walls proved all too penetrable. Incidentally, so, too, were those of Damascus, which — as Greene's audience would have known, thanks to Marlowe - Tamburlaine sacked in 1401. If the reference to Damas's walls could suggest vulnerability rather than security, so could Henry's fraught comparison of England to the walled city of Babel, rather than Semiramis's Babylon (also sacked by Tamburlaine), although the two were often conflated at the time. ${ }^{48}$ Since Babel's tower famously toppled, the allusion smacks of excessive pride and 
collapsing walls rather than unassailable ones. Lastly, the plain fact that the European monarchs have already crossed the Channel to attend Henry's political summit further conspires to undermine the confidence the king places in oceanic walls and cliffs.

These ambiguities persist in the final scene of the play, when Henry again addresses the foreign leaders: 'Glorious commanders of Europa's love, / That makes fair England like that wealthy isle / Circled with Gihon and swift Euphrates' (2143-5). Once again, the king's syntax reflects his desire to garner the benefits of international cooperation while retaining a distinct sense of English national identity. He acknowledges 'Europa's love' makes England wealthy, while the image of England as a 'circled' island underscores its separateness. Gihon and the Euphrates are two of four rivers mentioned in Genesis as issuing from paradise (from the Persian for 'walled garden'), and this fact makes an implicit comparison between England and Mesopotamia, the site of both Eden and Babylon, the walled city. The bible, however, also describes Gihon as encircling the land of Cush, believed to be Ethiopia. Whether Henry sees England as another Babylon, Damascus, Eden, or Ethiopia, none could properly be described as an unconquerable isle or invincible bastion. Friar Bacon is haunted by the sense that walls and buffers, whether natural or artificial, are not inviolable, but still yearns to cordon off England as a realm apart from Europe.

Despite the ingenious efforts of engineers like Ive, the latest designs in angular bastions to deflect cannon fire could not forestall the sense that the age of castles was nearing an end. As the peace-minded and cash-strapped King James imposed cutbacks on defence spending, many coastal forts fell further into disrepair, and the Stuart monarchy soon found adversaries enough within the realm. In 1629, two years after the republication of The Famous History, the divine John Andrews would remark that even a new-fangled brass wall is no guarantee of invulnerability: 'Wherefore, if all our Nauie were ready, all our Ports fortified; all our Coasts guarded; all our men strongly armed, and our Land inuironed with a wall of Brasse; yet it is to be feared, that wee haue a Traytor within vs, euen our long continued and vnrepented sinnes, that will draw Gods vengeance vppon us'. ${ }^{49}$ Since Greene's comedy was reprinted in 1630 with a blurb advertising it as 'lately played' by Prince Palatine's company, Andrews's 'wall of Brasse' could be yet another reference to Friar Bacon's wall, indicating that this magical barrier seemed even more unrealistic in the early decades of the seventeenth century.

The recognition of the impracticality of a national border wall for England did not, however, in any way tarnish its appeal as a metaphor. Rather than completely abandon the wall in the post-gunpowder era, some of Greene's contemporaries 
repurposed it as a symbol, contending that strong, capable government functioned as the best wall of all. Interestingly, a work of political theology published in 1589, and hence contemporaneous with the premiere of Friar Bacon and Friar Bungay, contends that England has enjoyed peace (despite being governed by a queen) because it has embraced the true faith of the Protestant Reformation:

We see that England, who hath mainteined the puritie of Gods lawes these 30 yeares, hath enioyed an assured peace vnder the handes of a woman, and yet such Realmes as be gouerned by men haue bene troubled: for that kingdome hath God preserued from both secret $\&$ open enemies, \& to that nation hath bene a wall of brasse. ${ }^{50}$

For bible-toting Protestants, who knew the Hebrew scriptures well, Elizabeth seemed to fulfil the words of Jeremiah 1:18, 'Behold, I this day have made thee a defenced citie, and an yron piller $\&$ walles of brasse against the whole land'. The same image resurfaces in Jeremiah 15:20, 'And I will make thee vnto this people a strong brasen wall'. Such passages provided a scriptural warrant that a godly monarch would be enough to deter or repel a foreign invasion, and may have been a vital cue for Greene or the author of The Famous Historie in having Bacon devise a brass wall.

This tribute to Elizabeth in The Reformed Politicke has an intriguing resonance with Bacon's final prophecy of a future ruler who will 'overshadow Albion with her leaves' (2127). While King Henry professes himself stumped by Bacon's mystical vision, Elizabethan audiences would have had no difficulty decoding 'Diana's rose' as an allusion to their queen. The rose had been a symbol of the Tudor dynasty since the reign of Elizabeth's grandfather Henry VII. The treelike rose seems a far more benign image of the English nation than the brass wall. Its function, however, in both defining and shielding the nation is very much the same. An enlightening comparison can be made with a metaphorical wall in another Renaissance play, William Rowley's The Birth of Merlin. While Rowley apparently knew the same story of Merlin's brazen wall around Carmarthen as Spenser and Drayton, he instead transforms it into a symbol of England's greatness. Aided by Merlin's 'Knowledge, Arts, Learning, Wisdom ... and Prophecy' (3.3.26-7), the nation will be unconquerable: 'His Art shall stand / A wall of brass to guard the Brittain land' (28-9). England's security derives from its cultural attainments rather than an actual wall. 'Art' does not necessarily exclude what Ive would call the 'Practise' of fortification, but the impact of the image is to shift attention from physical walls to figurative ones, from forts to fortitude. This manoeuvre is essentially the same one Bacon makes in the final scene of 
Greene's comedy. Bacon relinquishes his brass wall but not his vision of national autonomy and integrity. His prophecy is not an ode to multilateral harmony in European politics but of alliances that bolster English supremacy: Apollo's sunflower, Venus's hyacinth, Pallas's laurel, and Ceres's carnation (emblems of other dynasties) bow down in fealty to 'Diana's rose', and Henry's gloss is not far off: 'Thus glories England over all the west' (2155). Fittingly, one of the possible inspirations for Greene's magus, John Dee, was an ardent nationalist and one of the great visionaries of British imperialism. ${ }^{51}$ If Greene's play implies that a vast border wall is a chimera, it still arouses and half-satisfies a yearning for such a wall, and the security and national identity it would seem to bestow. Adam McKeown has recently remarked that the image of the nation as an embattled island fortress 'changed England spatially by projecting a consolidated country organized around military needs and confined by military infrastructure. ${ }^{52}$ In deploying the wall to effect the same change, Friar Bacon can dispense with the cumbersome chore of building a literal wall.

With the recent resurgence of nationalism in America and England, border walls have once again become high-voltage metaphors in geopolitics. For the sake of historical fidelity, one should note that Bacon envisions the wall as a bulwark against Catholic military invasion rather than immigration, as many Elizabethan immigrants were in fact Dutch and French Protestants seeking refuge from religious violence. To ignore that Tudor England was in many respects a 'thoroughly and unapologetically xenophobic society' would nevertheless be irresponsible. ${ }^{53}$ In the days of the Armada scare, the Florentine diplomat Petruccio Ubaldini remarked, 'It is easier to find flocks of white crows than one Englishman (and let him believe what he will about religion) that loves a foreigner. ${ }^{54}$ An anonymous libel (signed Tamburlaine) threatened to massacre the entire Dutch community in London in 1593, and Queen Elizabeth herself licensed the expulsion of 'negroes and blackamoors' from the realm in 1601. The shade of 'Diana's rose' did not shelter everyone. If the failure of Bacon's project speaks to declining confidence in walled forts in the age of gunpowder, the idea of it must have retained a certain appeal to many in early modern London, where an influx of immigrants incited resentment and uncertainty about what it meant to be English. Bacon's wish to build an impossibly large border wall and yet serve as the host and master of ceremonies for an alliance with Spain and Germany perfectly captures England's ambivalence about its niche in early modern Europe in an era of incipient globalization. The cumulative impression of the play's political rhetoric is, to quote Innogen's memorable quip on Anglo-European relations, that 'Britain seems as of it but not in it' (Cym 3.4.138). In Bacon's desire to reap the fruits of 
international cooperation and trade while maintaining a staunchly independent nationalist identity, Friar Bacon and Friar Bungay offers an uncanny parable for the predicament of post-Brexit Britain. 


\section{Notes}

1 D.E.W. Wormell, 'Walls of Brass in Literature', Hermathena 58 (1941), 116-20.

2 Lisa Hopkins, 'Profit and Delight?: Magic and the Dreams of a Nation', in Magical Transformations on the Early Modern English Stage, ed. Lisa Hopkins and Helen Ostovich (Aldershot, 2014), 139-54, 144, https://doi.org/10.4324/9781315593197.

3 Paola Zombelli, White Magic, Black Magic in the European Renaissance (Leiden, 2007), https://doi.org/10.1163/ej.9789004160989.i-282; Brian Clegg, Roger Bacon: The First Scientist (London, 2013).

4 Anonymous, The Famous Historie of Fryer Bacon (London, 1627; sTC: 1183), B4v.

5 Robert Greene, Friar Bacon and Friar Bungay, ed. Daniel Seltzer (Lincoln, 1963), and Friar Bacon and Friar Bungay, ed. J.A. Levin (London, 1969). John Henry Jones, meanwhile, proposes that an alternate version of the prose romance, The Most Famous Historie of the Learned Fryer Bacon, is closer to the version that Greene knew, and that its original publication was inspired by the success of the prose Faust Book. John Henry Jones, The English Faust Book: A Critical Edition Based on the Text of 1592 (Cambridge, 1994). The possibility that the prose romance was written to capitalize on the popularity of Greene's comedy deserves more serious consideration than it has yet received. If true, the wall scheme might be Greene's brainchild.

6 Christopher Marlowe, Doctor Faustus, ed. David Bevington and Eric Rasmussen (Manchester, 1993).

7 The fact that Greene's Alphonsus of Aragon imitates Marlowe's Tamburlaine increases the likelihood that Friar Bacon post-dates Faustus (rather than vice versa). See Marlowe, Doctor Faustus, 1; Jones, The English Faust Book, 55.

8 Edmund Spenser, The Faerie Queene, ed. A.C. Hamilton (Harlow, 2007).

9 Michael Drayton, The Works of Michael Drayton, ed. J. William Hebel (Oxford, 1933).

10 Jones, English Faust Book, 62. A brass wall also features in a prophecy allegedly made in 1569 and attributed to a conjuror who also appears in Greene's play, Tarquatus Vandermast. Giovanni Cipriano, A Strange and Wonderful Prophecy, trans. Anthony Hollaway (London, 1595; sTC: 5324.5), A3v.

11 Richard Helgerson, Forms of Nationhood: The Elizabethan Writing of England (Chicago, 1992); Jeffrey Knapp, An Empire Nowhere: England, America and Literature, from Utopia to The Tempest (Berkeley, 1992); Andrew Hadfield, Literature, Politics, and National Identity: Reformation to Renaissance (Cambridge, 1994); Claire McEachern, The Poetics of English Nationhood, 1590-1612 (Cambridge, 1996); Andrew Escobedo, Nationalism and Historical Loss in Early Modern England (Ithaca, 
2004), https://doi.org/10.7591/9781501723964; Philip Schwyzer, Literature, Nationalism, and Memory in Early Modern England and Wales (Cambridge, 2004), https://doi.org/10.1017/cbo9780511483950.

12 Adam McKeown, Fortification and its Discontents: Shakespeare to Milton (London, 2019), https://doi.org/10.4324/9781351108515.

13 McKeown has extended his arguments to the nation and Henry VIII's coastal fortifications in 'Walled Borders and the Geography of Power in Henrician Prose', English Literary Renaissance 48.2 (Spring 2018), 121-35, https://doi.org/10.1086/697521. McKeown discusses the pushback against the national wall by historians such as William Camden and John Speed rather than in utopian narratives or plays.

14 Barbara Traister, Heavenly Necromancers: The Magician in English Renaissance Drama (Columbia, 1984); Deanne Williams, 'Friar Bacon and Friar Bungay and the Rhetoric of Temporality', in Reading the Medieval in Early Modern England, ed. Gordon McMullan and David Matthews (Cambridge, 2007), 31-48; Brian Walsh, " "Deep Prescience": Succession and the Politics of Prophecy in Friar Bacon and Friar Bungay', Medieval and Renaissance Drama in England 23 (2010), 63-85.

15 Friar Bacon and Friar Bungay, ed. Christopher Matusiak, Queen's Men Editions, University of Victoria, 2019, http://qme.internetshakespeare.uvic.ca/doc/FBFB M/

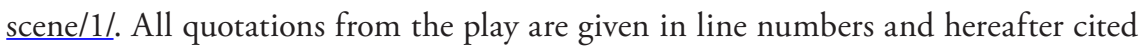
in text.

16 John Bridges, A Defence of the Gouernment Established in the Church of England (London, 1587), 738-9.

17 William Alley, Ptochhomuseioin (London, 1565; stc: 374), 47r-v. Italics added.

18 There has in fact been a sea-wall, known as Dymchurch Wall, protecting this section of the English coast since Roman times. In Roger Bacon's lifetime, another wall, known as the Rhee Wall, was constructed in nearby Romney Marsh.

19 Frank Ardolino, “'Thus glories England over all the West”: Setting as National Encomium in Friar Bacon and Friar Bungay', Journal of Evolutionary Psychology 9.3-4 (1988), 218-29.

20 Williams, 'Friar Bacon and the Rhetoric of Temporality', 43-4.

21 Traister, Heavenly Necromancers, 74.

22 Bryan Reynolds and Henry S. Turner, 'From Homo Academicus to Poeta Publicus: Celebrity and Transversal Knowledge in Robert Greene's Friar Bacon and Friar Bungay (c. 1589)', in Writing Robert Greene: Essays on England's First Notorious Professional Writer, ed. Kirk Melinkoff and Edward Gieskes (Aldershot, 2008), 73-94, https://doi.org/10.4324/9781315546162.

23 Francis Bacon, History of Henry VII (London, 1629; sтC: 1161), 231.

24 Thomas Browne, Pseudodoxia Epidemica (London, 1646; Wing: B5159A), 361. 
25 Peter Harrington, The Castles of Henry VIII (Oxford, 2007), 6.

26 Bacon listed some of the basic ingredients in his Opus Majus, ed. Robert Belle Burke (New York, 1962), 2:629-30, but refers to their use in pyrotechnics rather than artillery. Lynn Thorndike long ago demonstrated that another recipe for gunpowder in cipher is not accurate and its attribution to Bacon is possibly spurious. 'Roger Bacon and Gunpowder', Science 42 (1915), 799-800.

27 Charles Stephenson, 'Servant to the King for His Fortifications': Paul Ive and The Practise of Fortifications (Doncaster, 2008), 24.

28 Ibid., 10-11, 24. See 'Ive, Paul (fl 1602)', Oxford Dictionary of National Biography (DNB) (2018), https://doi.org/10.1093/ref:odnb/14496.

29 Christopher Marlowe, Tamburlaine, ed. J.S. Cunningham (Manchester, 1999).

30 Paul Ive, The Practise of Fortification (London, 1589; sтc: 1708.5), Aa3v-4r.

31 Charles Nicholl, The Reckoning: The Murder of Christopher Marlowe, 119-20. Also see Benjamin Bertram, Bestial Oblivion: War, Humanism, and Ecology in Early Modern England (New York, 2018), https://doi.org/10.4324/9781315201085.

32 Ive, Practise of Fortification, Aa2r. Ive dedicated his other military treatise, Instructions for the Wars (a translation of a work by Raimond de Beccarie de Pavie) to William Davison, Walsingham's chief assistant.

33 Scott McMillin and Sally-Beth MacLean, The Queen's Men and Their Plays (Cambridge, 1998); Locating the Queen's Men 1583-1603: Material Practice and Conditions of Playing 1583-1603, ed. Helen Ostovich, Holger Syme, and Andrew Griffin (New York, 2016), https://doi.org/10.4324/9781315592893.

34 Vin Nardizzi likewise sees Friar Bacon as an Armada play, and notes that the rumours that the Spanish invaders intended to burn down the Forest of Dean and thus cripple England's navy 'adds a certain appeal to Bacon's plan to protect England with bronze [sic] walls' (51). Wooden Os: Shakespeare's Theatres and England's Trees (Toronto, 2013), https://doi.org/10.3138/9781442664173.

35 The word bronze was imported from the Italian and initially applied to ancient art works; the first recorded appearance of bronze in the $O E D$ dates from 1739.

36 Qtd in David Childs, Tudor Sea Power: The Foundations of Greatness (Barnsley, 2009), 61.

37 Henslowe's Diary, ed. R.A. Foakes (Cambridge, 2002), 16-21.

38 Lawrence Manley and Sally-Beth MacLean, Lord Strange's Men and Their Plays (New Haven, 2014), 93-4, https://doi.org/10.12987/yale/9780300191998.001.0001.

39 Stephenson, 'Servant to the King for His Fortifications', 22.

40 Henslowe's Diary, 207.

41 Walsh, 'Deep Prescience', 64.

42 Ibid., 77. 
43 Anonymous, Nobody and Somebody (London, 1606; sTC: 18597), D3r.

44 John Marston, Parasitaster, or the Fawn (London, 1606; sтc: 17484), B2r.

45 All Shakespearean quotations are from The Oxford Shakespeare, ed. Gary Taylor et al. (Oxford, 2016).

46 Schwyzer, Literature, Nationalism and Memory in Early Modern England and Wales, 4-5.

47 In A Midsummer Night's Dream, Shakespeare ridicules a hapless band of players who presume to bring a wall on stage. As Bottom's bombastic impression of Hercules likely spoofs Edward Alleyn's performance of the role at the Rose, and as Bacon explicitly compares his wall to the Babylonian walls of Ninus, whose tomb serves as a rendezvous point for Pyramus and Thisbe, Snout's ludicrous impersonation of a wall would conceivably remind playgoers of Bacon's failed wall. For more on Bacon's place in the repertory, see Tom Rutter, Shakespeare and the Admiral's Men: Reading Across Repertories on the London Stage (Cambridge, 2017), 62-70.

48 Per Sivefors, 'Conflating Babel and Babylon in Tamburlaine 2', Studies in English Literature 52.2 (2012), 293-323, https://doi.org/10.1353/sel.2012.0018.

49 The Converted Man's New Birth (London, 1629; sтc: 11372), 3.

50 Jean de Frégeville, The Reformed Politicke (London, 1589), 62-3.

51 William Sherman, John Dee: The Politics of Reading and Writing in the Renaissance (Amherst, 1995), 149.

52 McKeown, 'Walled Borders and the Geography of Power in Henrician Prose', 121.

53 Schwyzer, Literature, Nationalism, and Memory in Early Modern England and Wales, 1.

54 Qtd in Garrett Mattingly, The Armada (Boston, 1988), 344. 